\title{
Methane emission estimates using chamber and tracer release experiments for a municipal waste water treatment plant
}

\author{
C. E. Yver Kwok ${ }^{1}$, D. Müller ${ }^{2}$, C. Caldow ${ }^{3}$, B. Lebègue ${ }^{1}$, J. G. Mønster ${ }^{4}$, C. W. Rella ${ }^{5}$, C. Scheutz ${ }^{4}$, M. Schmidt ${ }^{1,6}$, \\ M. Ramonet ${ }^{1}$, T. Warneke ${ }^{2}$, G. Broquet ${ }^{1}$, and P. Ciais ${ }^{1}$ \\ ${ }^{1}$ Laboratoire des Sciences du Climat et l'Environnement (LSCE/IPSL), CNRS-CEA-UVSQ, Centre d'Etudes Orme des \\ Merisiers, Gif sur Yvette, France \\ ${ }^{2}$ Institute of Environmental Physics, University of Bremen, Otto-Hahn-Allee 1, 28359 Bremen, Germany \\ ${ }^{3}$ Centre for Atmospheric Chemistry, University of Wollongong, Wollongong, NSW, 2522, Australia \\ ${ }^{4}$ Department of Environmental Engineering, Technical University of Denmark, Bygningstorvet - \\ Building 115, 2800 Lyngby, Denmark \\ ${ }^{5}$ Picarro Inc., 3105 Patrick Henry Drive, Santa Clara, CA, USA \\ ${ }^{6}$ Institut für Umweltphysik, University of Heidelberg, Heidelberg, Germany
}

Correspondence to: C. E. Yver Kwok (camille.yver@1sce.ipsl.fr)

Received: 9 December 2014 - Published in Atmos. Meas. Tech. Discuss.: 19 March 2015

Revised: 19 June 2015 - Accepted: 24 June 2015 - Published: 17 July 2015

\begin{abstract}
This study presents two methods for estimating methane emissions from a waste water treatment plant (WWTP) along with results from a measurement campaign at a WWTP in Valence, France. These methods, chamber measurements and tracer release, rely on Fourier transform infrared spectroscopy and cavity ring-down spectroscopy instruments. We show that the tracer release method is suitable for quantifying facility- and some process-scale emissions, while the chamber measurements provide insight into individual process emissions. Uncertainties for the two methods are described and discussed. Applying the methods to $\mathrm{CH}_{4}$ emissions of the WWTP, we confirm that the open basins are not a major source of $\mathrm{CH}_{4}$ on the WWTP (about $10 \%$ of the total emissions), but that the pretreatment and sludge treatment are the main emitters. Overall, the waste water treatment plant is representative of an average French WWTP.
\end{abstract}

\section{Introduction}

Human activities cause greenhouse gas (GHG) emissions at a large scale, changing the atmospheric chemical composition by measurable and consequential amounts. Anthropogenic GHG emissions such as methane $\left(\mathrm{CH}_{4}\right)$ now represent a significant fraction of total greenhouse gas emissions into the atmosphere. To better understand the anthropogenic sources of GHGs, with the goal of ultimately reducing these emissions, it is essential to accurately quantify the emissions at different spatial scales, from the country to the process scale, and to monitor the possible temporal variabilities. We can sort estimation methods into two groups depending on the type of measurement used: the top-down approach based on atmospheric measurements of GHGs at different scales (global, regional, local) and the bottom-up approach that uses activity data, emission factors and flux modeling to calculate emissions. Both approaches can be applied from the global to the process scale depending on the representativity of the measurements.

Methane is a potent anthropogenic greenhouse gas with a global warming potential 28 times as strong as that of $\mathrm{CO}_{2}$ on a 100-year time horizon (Stocker et al., 2013). Primary sources of anthropogenic methane emissions are landfills, waste water treatment plants (WWTPs), rice paddies, ruminants and manure management, oil and gas production and transport activities. Combining the two approaches by using top-down measurements at all scales to validate or adjust benchmark bottom-up calculations and emission factors can help not only improve inventories by a more robust quantification but also provide valuable information for how to prioritize emission reduction activities. 

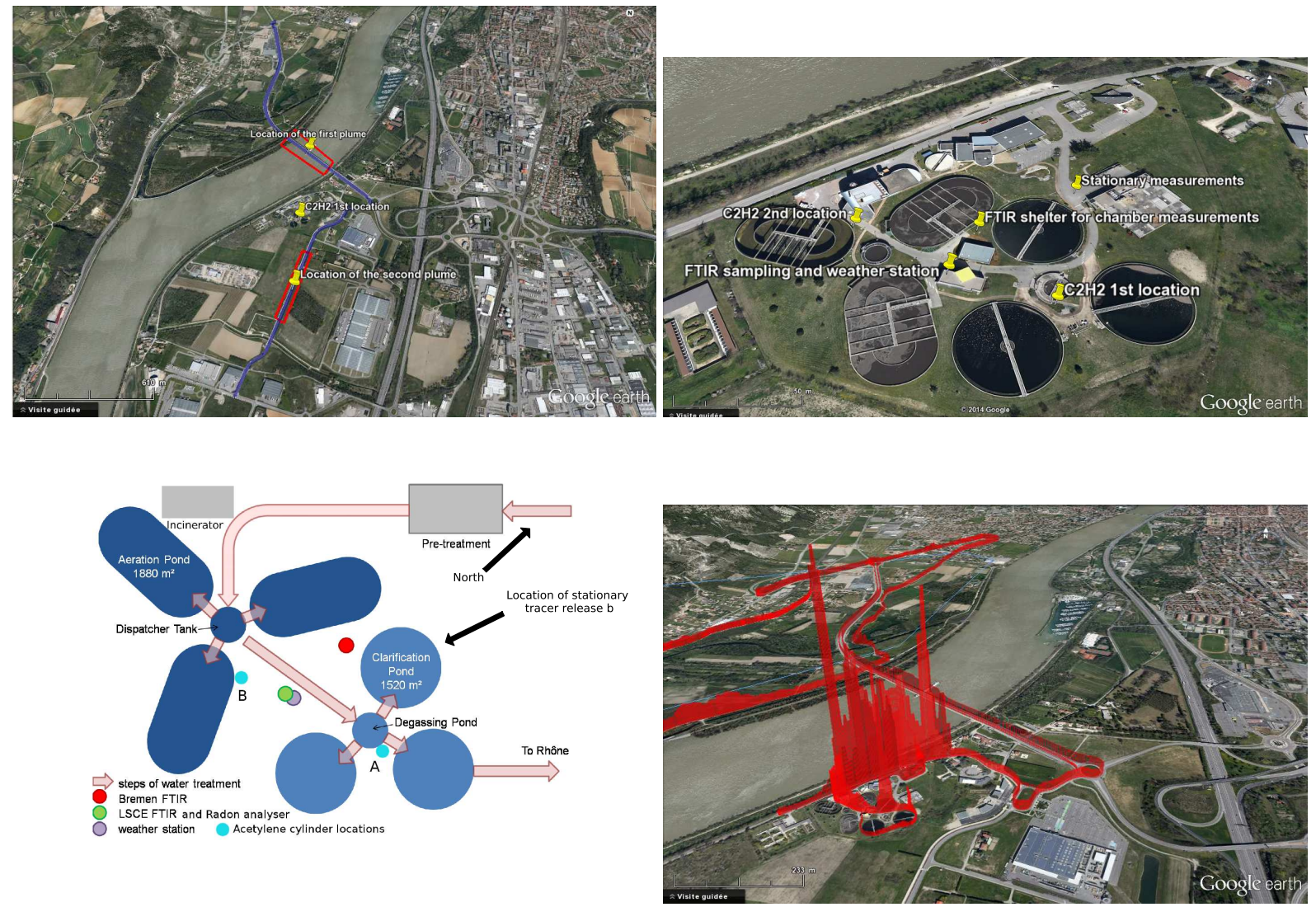

Figure 1. (a and b) Aerial view (Google Earth) of the WWTP. The blue lines show the driving paths during the tracer release experiment and the red rectangles show the location of the plumes. (c) Schematic view of the waste water treatment plant. (d) Aerial view of the WWTP with methane concentrations shown as red rectangles measured on 18 September with a northeast wind. The signals showed are above $1850 \mathrm{ppb}$. The highest signal near the incinerator is $10 \mathrm{ppm}$.

In France, methane emissions from waste management (waste water treatment and landfills) accounted for about $19 \%$ of the total methane emissions in 2011 following the national inventory from CITEPA (CITEPA, 2013). Landfills are the largest emitter with $17 \%$, but waste water treatment plants still represent a non-negligible part (2\%). However, these values are estimated with $100 \%$ uncertainty due to the difficulty in accurately estimating the biological demand of oxygen (BOD), quantity of $\mathrm{CH}_{4}$ emitted by $\mathrm{kg}$ of BOD, fraction of treated incoming waste water and anoxic/oxic conditions, which are the parameters used by CITEPA to derive $\mathrm{CH}_{4}$ emissions from WWTP (CITEPA, 2013). Several studies have been conducted in different countries to provide more accurate estimates of the emissions for WWTPs. Cakir and Stenstrom (2005) and El-Fadel and Massoud (2001) present estimations based on process modeling, but some studies such as Czepiel et al. (1993), Wang et al. (2011) and Daelman et al. (2012) calculate emissions using $\mathrm{CH}_{4}$ measurements with mass budget. Finally, a recent study by Yoshida et al. (2014) used the tracer release method as described in this paper to estimate $\mathrm{CH}_{4}$ and $\mathrm{N}_{2} \mathrm{O}$ emissions from a WWTP. In these papers, emissions vary from 0.011 to $1.3 \mathrm{~kg} \mathrm{yr}^{-1}$ per population equivalent depending on the WWTP design (e.g., depending on the use of aerobic or anaerobic processes, presence of a sludge digester) and the estimation method as the tracer release allows the capturing of leakage emissions that could be omitted by the other methods. For municipal WWTPs using activated sludge (aerobic) treatment, emissions still vary from 0.039 to $0.309 \mathrm{~kg} \mathrm{yr}^{-1}$ per population equivalent. This range of estimate shows that the WWTP $\mathrm{CH}_{4}$ emissions depend on the design and the size of the WWTP. In France, according to the BDERU for 2008 (database for urban waste water, http://www.statistiques. developpement-durable.gouv.fr/lessentiel/ar/306/1168/ assainissement-traitement-collectif-eaux-usees.html), there are about 18600 WWTPs, half of which treat water for a fewer-than-500 population equivalent. However, the $6 \%$ of WWTP with more than 10000 population equivalent treat $80 \%$ of the waste water. In this study, we focused on one of these medium-sized WWTPs that employs activated sludge treatment. We used two methods - chamber measurements and tracer release method with acetylene - that have been 
rarely used on WWTPs to calculate GHG emissions at the process and the plant scale. We aimed not only to estimate the total emissions of the site but also to investigate individual processes and evaluate the missing elements between these two measurement scales. Another goal was to estimate the uncertainties for each method to provide a more robust emission estimation and be able to compare our results with other studies or inventories. An intensive measurement campaign was thus conducted at one of the WWTP of Valence, France, from 17 to 21 September 2012.

First, we present the details of the site under study, followed by the different emission estimation methods, measurement techniques and instruments employed during the experimental campaign. Finally, we present and discuss the results obtained for $\mathrm{CH}_{4}$ from the process scale up to the site scale. All the emission estimates hereafter refer directly to $\mathrm{CH}_{4}$, i.e., the notation $\mathrm{kg}$ of $\mathrm{CH}_{4}$ day $^{-1}$ or $\mathrm{kg}$ of $\mathrm{CH}_{4} \mathrm{yr}^{-1}$ per population equivalent is replaced by $\mathrm{kg} \mathrm{day}^{-1}$ or $\mathrm{kg} \mathrm{yr}^{-1}$ per population equivalent.

\section{Description of the site}

The WWTP is located in the southwest of the city of Valence, around $50 \mathrm{~m}$ east from the Rhône river, which flows in a north-south direction (see Fig. 1). Valence is located in the southeastern part of France, $500 \mathrm{~km}$ southeast of Paris, $100 \mathrm{~km}$ south of Lyon and $70 \mathrm{~km}$ southwest of Grenoble. The station is managed by Veolia France and treats the water for 150000 inhabitant equivalents, which represents about $2800 \mathrm{~m}^{3} \mathrm{~h}^{-1}$ with an exiting BOD of $35 \mathrm{~kg} \mathrm{~m}^{-3}$ (http://www. valenceagglo.fr/stations-depuration).

The water follows a several step treatment (see Fig. 1). After being filtered for solids, the water is filtered for sand particles (down to 200 microns in diameter) by sedimentation, and oil is removed by injection of air bubbles. The water is then distributed to three aeration basins $\left(12000 \mathrm{~m}^{3}\right.$ each) via a dispatcher basin. In the aeration basins, air is periodically injected to help aerobic bacteria to digest the organic matter. The water and the sludge are sent to a degassing/dispatcher basin and then separated by sedimentation inside three clarification basins $\left(6000 \mathrm{~m}^{3}\right.$ each). The sludge from the different steps is collected and dried before being incinerated. The cleaned water from the overspill of the clarification basins is discharged into the Rhône river. During the campaign, one of the aeration basins was being cleaned, so only two were in use.

We anticipated the potential for methane release during all steps of the process. In the aeration basins, periods of aeration with aerobic reaction alternate with rests when anaerobic reactions can occur. Methane formed during these resting phases is then transported to the surface when aeration restarts and provokes a mixing of water. In the degassing basin, water is mixed and dissolved methane can be released. In the clarification basin, as there is a slow mixing, some de- gassing could still be expected, with bacteria from the active sludge still producing methane. Finally, the sludge may still contain methane that could be emitted during centrifugation, storage and incineration. In addition, methane dissolved in the incoming water from the city will be released at the plant, starting from the first exposure to the atmosphere, and certainly during the aeration process. Figure $1 \mathrm{~d}$ shows a qualitative image of the methane measured with the mobile instrument described in Sect. 4 around the site on 18 September with a southwest wind. We indeed see higher $\mathrm{CH}_{4}$ concentrations on the site than outside with peaks for the degassing basin, the water pretreatment and the sludge incinerator.

\section{Emission estimation methods}

\subsection{Chamber measurements on the basins}

Depending on the basin areas under investigation, two different modes of chamber measurements were employed: (a) accumulation closed-chamber measurements (Frankignoulle, 1988) and (b) flow-through open-chamber measurements. The former mode was employed on the clarification basin (18 September) and on the aeration basin (19 September) outside of the aerated area of the basin, which had rather calm surfaces, and the latter on the aerated part of the aeration basin, where air is injected in the basin, resulting in a large air flux and turbulent surface (see Figs. 2 and 3).

\section{Accumulation (closed-chamber) measurements}

The chamber was closed against ambient air and the mass flux $F$ is calculated from the linear increase of the measured gas mole fraction in the chamber with time (see Fig. 3a):

$F=\frac{\Delta C}{\Delta t} \frac{p V M A_{\text {basin }}}{R T A}$,

where $\frac{\Delta C}{\Delta t}$ is the fitted linear increase of the gas mole fraction in the chamber with time $\left(\mathrm{mol} \mathrm{mol}^{-1} \mathrm{~s}^{-1}\right), p$ is the pressure in the floating chamber $(\mathrm{Pa}), T$ the temperature $(\mathrm{K}), R$ the universal gas constant $\left(8.314 \mathrm{~m}^{3} \mathrm{~Pa} \mathrm{~K}^{-1} \mathrm{~mol}^{-1}\right), V$ represents the volume of the chamber $\left(\mathrm{m}^{3}\right), A$ the water surface area enclosed by the chamber $\left(\mathrm{m}^{2}\right), A_{\text {basin }}$ the area of the basin $\left(\mathrm{m}^{2}\right)$ and $M$ the molar mass of methane $\left(\mathrm{g} \mathrm{mol}^{-1}\right)$. Fluxes were converted to the unit $\mathrm{g} \mathrm{day}^{-1}$. The chamber had a small vent hole (ca. $10 \mathrm{~mm}$ in diameter). When the chamber was first placed on the water, it was vented to the atmosphere to allow the chamber pressure equalize to atmospheric pressure. After about $20 \mathrm{~s}$, the vent was closed. Ambient pressure was recorded at the weather station.

As for the errors, five main sources of uncertainty were considered. First, the error associated with the linear fit was taken into account and calculated as the coefficient of variation (CV). Secondly, the uncertainty associated with the volume of the chamber was considered. This uncertainty arises both from the initial measurement of the total volume of the 
A

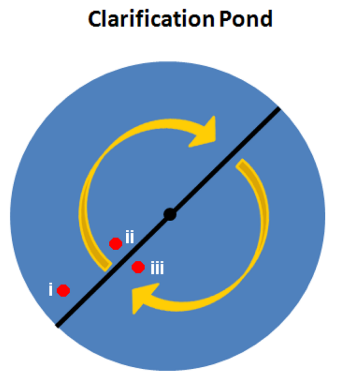

B

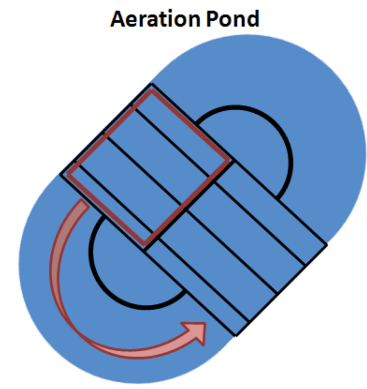

Figure 2. Schematic of the two basins that were measured with the floating chamber. (a) Clarification basin: the yellow arrow shows the direction in which the arm rotates. The red dots and symbols refer to the location of the chamber during runs 1,2, 3 (symbol i), 4, 5, 7 (symbol ii) and 6, 8, 9 (symbol iii). (b) Aeration basin: the red rectangle denotes the aeration area, the arrow the water flow.

chamber and the uncertainty associated with the water level in the chamber. Because of the conic shape of the chamber, the uncertainty of the water level also affected the uncertainty of the water surface area enclosed by the chamber. Here it was assumed that the water level varied by $1 \mathrm{~cm}$. The uncertainties associated with the pressure and temperature sensors were also considered in terms of the confidence interval provided by the manufacturer. The overall uncertainty was calculated for each run using propagation of uncertainties (Bevington and Robinson, 2003).

\section{Flow-through (open-chamber) measurements}

The chamber was modified for flow-through measurements with five small holes (ca. $10 \mathrm{~mm}$ in diameter) present in the top of the chamber to allow excess injected air to escape. During aeration times, the air in the chamber was replaced within a few minutes. Hence, the gas concentration in the chamber represented the concentration in the aeration air emitted from the basin once several mixing times in the chamber volume had occurred. Therefore, the mass flux of the emitted gas could be calculated by the amount of injected air, the gas concentration in the injected air and its integration over time (see Fig. 3b):

$F=\sum_{t}\left(C_{\text {chamber }}-C_{\text {background }}\right) \frac{M}{V_{\mathrm{m}}} \frac{\mathrm{d} V_{\text {Aeration }}}{\mathrm{d} t} A_{\text {aeration }}$,

where $C_{\text {chamber }}$ is the gas mole fraction measured in the chamber $\left(\mathrm{mol} \mathrm{mol}^{-1}\right), C_{\text {background }}$ is the background gas mole fraction in the injected air, $\frac{\mathrm{d} V_{\text {aeration }}}{\mathrm{d} t}$ is the volume of air injected inside the basin per time $\left(\mathrm{m}^{3} \mathrm{~h}^{-1}\right), M$ is the molar mass of $\mathrm{CH}_{4}\left(\mathrm{~g} \mathrm{~mol}^{-1}\right), V_{\mathrm{m}}$ is the molar volume of ideal gases $\left(\mathrm{m}^{3} \mathrm{~mol}^{-1}\right)$ and $A_{\text {aeration }}$ is the surface area of the aeration area in the aeration basin. The volume of air injected in the aeration basins was monitored with an Endress + Hauser AT70 flowmeter. The uncertainty given by the manufacturers is $2 \%$. The air injected into the aeration basin was ambient

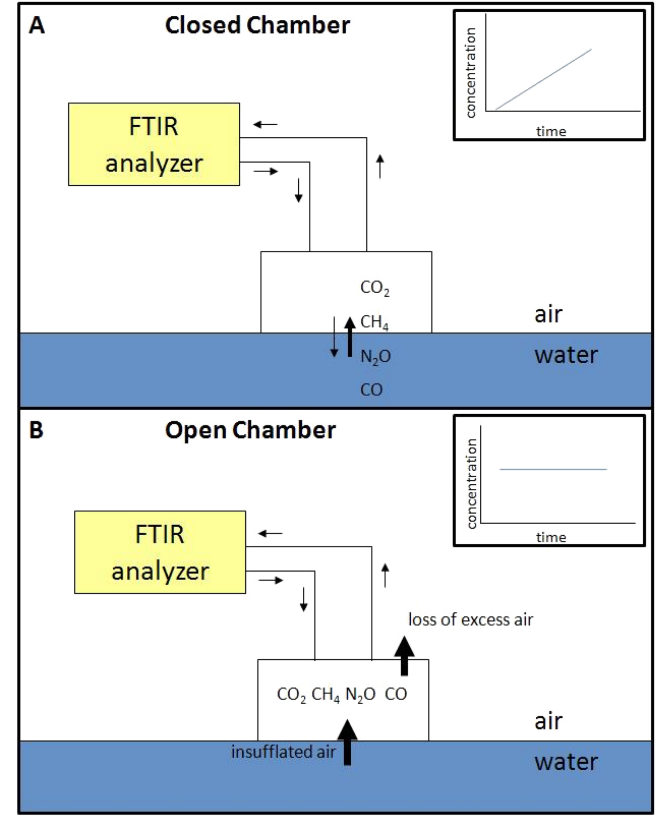

Figure 3. Schematic showing different modes of chamber deployment. (a) Conventional floating chamber used on a calm surface (accumulation closed-chamber measurements). The schematic concentration vs. time points out how the gas accumulates in the chamber over time (in case of a positive net flux from water to air). This increase is linearly approximated and from the slope, the flux is calculated. (b) Flow-through open chamber: the excess air escapes and the concentration measured in the chamber relates directly to the concentration in the emitted air. Thus, here we refer to the concentration reached in one time interval.

air. Note that multiplication with $A_{\text {aeration }}$ contains the assumption that air is injected homogeneously in the basin. As the air is released from approximately evenly spaced diffusors at the bottom of the basin, we think that this assumption is warranted. The uncertainty was then calculated with error propagation, taking into account both the uncertainty of the injected air volume (2\%), the uncertainty of the background $\mathrm{CH}_{4}$ concentration and the error of the $\mathrm{CH}_{4}$ measurement.

\subsection{Tracer release method}

The tracer release method consists of releasing a tracer gas (here $\mathrm{C}_{2} \mathrm{H}_{2}$ ) at a known rate from a location which is collocated with the unknown emission of a trace gas to be determined, here $\mathrm{CH}_{4}$. This method has often been used in previous studies to determine $\mathrm{CH}_{4}$ from landfills and more recently WWTPs (Czepiel et al., 1996; Galle et al., 2001; Spokas et al., 2006; Fredenslund et al., 2010; Mønster et al., 2014b; Yoshida et al., 2014). Concentrations of the tracer as well as the gas of interest are measured using a mobile instrument downwind in the co-propagating plumes. The ratio of the area of the two plume signals is proportional to the emission rate. Thus, knowing the emission rate of the released gas 
Table 1. Instruments used during the campaign and their specifications.

\begin{tabular}{llll}
\hline Instrument & Integration time used in the study & Species & Uncertainty for species of interest \\
\hline FTIR LSCE & $1 \mathrm{~min} / 30 \mathrm{~min}$ & $\begin{array}{l}\mathrm{CO}_{2}, \mathrm{CH}_{4}, \mathrm{~N}_{2} \mathrm{O}, \mathrm{CO} \text { and } \\
\delta^{13} \mathrm{C}\end{array}$ & $<0.1 \%\left(\mathrm{CH}_{4}\right)$ \\
FTIR Bremen & $5 \mathrm{~min}$ & $\begin{array}{l}\mathrm{CO}_{2}, \mathrm{CH}_{4}, \mathrm{~N}_{2} \mathrm{O}, \mathrm{CO} \text { and } \\
\delta^{13} \mathrm{C}\end{array}$ & $<0.1 \%\left(\mathrm{CH}_{4}\right)$ \\
\hline CRDS & $1 \mathrm{~s} / 1 \mathrm{~min}$ & $\mathrm{CH}_{4}, \mathrm{CO}_{2}, \mathrm{C}_{2} \mathrm{H}_{2}, \mathrm{H}_{2} \mathrm{O}$ & $<0.1 \%\left(\mathrm{CH}_{4}\right),<5 \%\left(\mathrm{C}_{2} \mathrm{H}_{2}\right)$ \\
\hline Weather station & $1 \mathrm{~min}$ & $\begin{array}{l}\text { Wind speed, wind direc- } \\
\text { tion, temperature, relative } \\
\text { humidity and atmospheric } \\
\text { pressure }\end{array}$ & \\
& & & \\
& &
\end{tabular}

and the concentrations of both gases, we could calculate the emission rate of the gases of interest:

$F_{\mathrm{CH}_{4}}=F_{\mathrm{C}_{2} \mathrm{H}_{2}} \frac{A_{\mathrm{CH}_{4}}}{A_{\mathrm{C}_{2} \mathrm{H}_{2}}} \frac{M_{\mathrm{CH}_{4}}}{M_{\mathrm{C}_{2} \mathrm{H}_{2}}}$,

where $F_{\mathrm{CH}_{4}}$ are the emissions of $\mathrm{CH}_{4}\left(\mathrm{kgh}^{-1}\right), F_{\mathrm{C}_{2} \mathrm{H}_{2}}$ are the known emissions of $\mathrm{C}_{2} \mathrm{H}_{2}\left(\mathrm{~kg} \mathrm{~h}^{-1}\right), \frac{A_{\mathrm{CH}_{4}}}{A_{\mathrm{C}_{2} \mathrm{H}_{2}}}$ is the ratio of the areas under the signals of $\mathrm{CH}_{4}$ and $\mathrm{C}_{2} \mathrm{H}_{2}$ once the background subtracted and $\frac{M_{\mathrm{CH}_{4}}}{M_{\mathrm{C}_{2} \mathrm{H}_{2}}}$ is the ratio of the molar masses of $\mathrm{CH}_{4}$ and $\mathrm{C}_{2} \mathrm{H}_{2}$. For stationary experiments, Eq. (3) was modified such that the slope of the $\mathrm{CH}_{4}$ vs. $\mathrm{C}_{2} \mathrm{H}_{2}$ linear regression was used to calculate the unknown flux instead of the area under the signals. Indeed, in this case, as there was no crossing of the plumes, there is no area under the signals to integrate but instead a mixed signal varying with the wind direction.

In this method, the uncertainties arise then from the concentration measurements, the tracer flux and the collocation of the plumes. $\mathrm{CH}_{4}$ and $\mathrm{C}_{2} \mathrm{H}_{2}$ concentration errors are less than 0.1 and $5 \%$, respectively, for $1 \mathrm{~s}$ average. Once the gas cylinder is installed and regulated, the flow of the tracer gas is steady and well known, and this error depends on the precision, the reproducibility (given by the manufacturer) and the reading error. The precision is defined by the maximum value that the flowmeter can read and is here below $2 \%$ on $1507 \mathrm{Lh}^{-1}$ (Mønster et al., 2014a). The reproducibility on the read flow is $0.5 \%$ and the reading error is estimated as a quarter the size of the float, i.e., $1 \mathrm{~mm}$. Thus the maximum total uncertainty on the $\mathrm{C}_{2} \mathrm{H}_{2}$ flow is $0.5 \mathrm{~kg}_{\text {day }}{ }^{-1}$ with the precision being the major factor.

The main uncertainties come from the imperfect collocation of the plumes and from the analysis of the plumes, especially the background determination for $\mathrm{CH}_{4}$ and the calculation of the areas, as the signal/noise ratio is not very high in this study. Indeed, even while driving several hundreds of meters out of the plumes, in the "WWTP-free" air, the background for $\mathrm{CH}_{4}$ was still highly variable from one crossing to the other. To address this issue, the background for each $\mathrm{CH}_{4}$ plume was calculated using a linear regression between the first and last point of the peak instead of removing an average background value for the whole event. Once this background was subtracted, the ratio of the areas was calculated. $\mathrm{C}_{2} \mathrm{H}_{2}$ background values were almost 0 , so no background was subtracted. We used $1 \mathrm{~s}$ averaged data. Indeed, the more data points are used, the better the resolution of the signal is, allowing for a finer area estimation, which is the observation we are looking to extract. The autocorrelation of the errors on the $1 \mathrm{~s}$ data is taken into account in the global error which is the aggregation of the different errors. To estimate the non-collocation error, we ran one experiment with the $\mathrm{C}_{2} \mathrm{H}_{2}$ cylinder at a different location; however, due to the small amplitudes of the signal as well as the $\mathrm{CH}_{4}$ high noise, these data could not be used quantitatively. To reduce this error as much as possible, we drove far enough away as was convenient with the existing roads (500 $\mathrm{m}$ to $1 \mathrm{~km}$ away) to consider the two signals collocated. The goal is also to position the cylinder such as it is neither downwind nor upwind of the $\mathrm{CH}_{4}$ source to minimize dispersion discrepancies. We also discuss this assumption qualitatively in Sect. 5.

\section{Instruments and setup}

During this 1-week campaign, two Fourier transform infrared (FTIR) analyzers measuring $\mathrm{CO}_{2}, \mathrm{CH}_{4}, \mathrm{~N}_{2} \mathrm{O}, \mathrm{CO}$ and $\delta^{13} \mathrm{C}$ in $\mathrm{CO}_{2}$ (Ecotech and University of Wollogong, Australia), one cavity ring-down spectroscopy (CRDS) instrument (custom prototype, Picarro Inc., Santa Clara) measuring $\mathrm{CH}_{4}$, $\mathrm{CO}_{2}$ and $\mathrm{H}_{2} \mathrm{O}$ or $\mathrm{C}_{2} \mathrm{H}_{2}, \mathrm{CH}_{4}$ and $\mathrm{H}_{2} \mathrm{O}$ and a weather station were installed to measure GHG concentrations and/or estimate $\mathrm{CH}_{4}$ emissions (see Fig. 1 and Table 1). Here, we focused only on $\mathrm{CH}_{4}$ and $\mathrm{C}_{2} \mathrm{H}_{2}$ concentrations even though the instruments measured more species. One of the FTIR analyzers was used to measure samples from the basins with the chamber technique described above and the second mostly sampled air at the same location as the weather station but performed some measurements above the basins as well. These ambient air measurement gave a general picture of the conditions during the campaign and the concentration variability. The CRDS instrument, used for the tracer release 
method, was installed in a car along with a real-time GPS device and was thus mobile except for a one-night-long comparison with the FTIR. The instrumental techniques and the setup of the instruments during the campaign are detailed hereafter.

\subsection{FTIR analyzers}

An FTIR analyzer records a spectrum over a broad IR range $\left(1800-5000 \mathrm{~cm}^{-1}\right)$, thereby offering the possibility of measuring a large number of species simultaneously. Spectra are stored and can be analyzed at a later date with a different method to get data with a higher accuracy or study new species. In the FTIR, the infrared signal passes first through a Michelson interferometer, then this modulated beam traverses the sample cell. The resulting time-modulated signal is then converted into an infrared spectrum through Fourier transform. The FTIR analyzer operated by the LSCE is a commercially available Ecotech instrument. The instrument operated by the Bremen University was built at the University of Wollongong, Australia. Both instruments are functionally identical. A detailed description is found in Griffith et al. (2012) and Hammer et al. (2012). Briefly, each of the two instruments consists of a commercially available FTIR interferometer (IRcube, Bruker Optics, Germany) with a $1 \mathrm{~cm}^{-1}$ resolution coupled with a $3.5 \mathrm{~L}$ multi-pass cell with a $24 \mathrm{~m}$ optical path length (PA-24, InfraredAnalysis, Anaheim, USA). The cell and the interferometer are put together on an optical bench inside a temperature-controlled chamber. An in situ PT100 platinum resistance thermometer and a pressure sensor (HPM-760s, Teledyne Hastings, USA) are installed on the multi-pass cell. Nitrogen (grade 4.5) is used to purge the interferometer housing as well as the transfer optics between the cell and the interferometer. A drying system composed of a 24 in counter-flow Nafion dryer (Permapure, Toms River, NJ, USA) followed by a chemical dryer $\left(\mathrm{Mg}\left(\mathrm{ClO}_{4}\right)_{2}\right)$ was located upstream from the cell.

During the campaign, both instruments were installed in small shelters without air conditioning. The first one, operated by LSCE, was installed to sample ambient air above the whole station for the majority of the time. During the last day, air was sampled above different basins. For this instrument, the pressure of the cell is controlled using a mass flow sensor mounted at the outlet of the cell, and the flow is controlled by another mass flow controller installed upstream from the drying system. Four calibration gases and a control gas were used regularly during the 5 days of the campaign for calibration (once a day, $45 \mathrm{~min}$ for each calibration gas) and quality control (every 3-4h). During these 5 days, the temperature inside the shelter sometimes exceeded $30^{\circ} \mathrm{C}$. In order to keep the performances unchanged, the FTIR and the cell were kept at $32^{\circ} \mathrm{C}$ instead of the typical $30^{\circ} \mathrm{C}$. However, the temperature variations in the shelter were leading to cell temperature fluctuations, and therefore the reproducibility error was higher than in the laboratory ( 0.01 vs. $0.005 \%$, respectively).
The main sampling inlet was installed on top of a building located between the clarification and the aeration basins at about $7 \mathrm{ma}$ a.g.l. Ambient air measurements took place from 17 September 17:00 to 20 September 2012 14:00 and then from 20 September 18:30 to 21 September 2012 05:00. During the afternoon of 20 September, measurements above the clarification, the aeration and the degassing basins were taken with the LSCE FTIR analyzer sampling inlet $50 \mathrm{~cm}$ above the basins to compare with the ambient sampling.

The second FTIR was operated by the Bremen University and was used to analyze samples from a floating chamber operated on the clarification and the aeration basins. Due to the complexity of moving the shelter or deploying longer lines, no other places, such as the pretreatment area, could be measured with the chamber. The chamber consisted of a large upside-down flower pot surrounded by a tractor tire inner tube, which served as a floating device. The edge of the flower pot was filled with water, so that the chamber was sealed with respect to the water surface. The edge extended $3 \mathrm{~cm}$ into the water. A $12 \mathrm{~V}$ computer fan inside the chamber ensured mixing of the air in the chamber. The volume of the chamber was $0.10 \mathrm{~m}^{3}$, and the surface area of the water in the chamber was $0.28 \mathrm{~m}^{2}$. The chamber was connected to the FTIR in situ analyzer using PFA sampling lines and air from the chamber was circulated in a closed loop through the analyzer with a flow rate of $0.06 \mathrm{~m}^{3} \mathrm{~h}^{-1}$. The data were calibrated using a suite of secondary standards measured once during the campaign with methane concentrations ranging from 1.8 to $40 \mathrm{ppm}$.

On the clarification basin, chamber placements aimed to capture spatial flux variations and covered three approximate positions as indicated in Fig. 2a. The clarification basin possessed a rotating arm, or mixer, that was used to gently stir the basin and encourage the drainage of benthic sludge towards and out of a central hole at the bottom of the basin. Whilst the mixer was on, the floating chamber was tethered to the rotating arm and moved very slowly with the arm. Consequently, whilst sampling, the chambers moved about onehalf to one full rotation around the basin. The movementinduced turbulence was assumed to have a negligible effect on the flux, as the arm rotated at a slow rate, covering one rotation of $360^{\circ}$ in approximately $30 \mathrm{~min}$. Fluxes were calculated from the accumulation of methane in the chamber over time (closed chamber), as described above. On the aeration basin, two floating chamber measurements were conducted outside the aeration area. Focus was laid on measurements in the area where the aeration took place. Due to the high air flux in the aeration area, closed-chamber measurements were not suitable. Instead, we modified the setup and operated the chamber as open chamber over night (19-20 September), as detailed previously. 


\subsection{CRDS analyzer}

For the mobile tracer release measurement, we used an acetylene/methane/carbon dioxide/water vapor analyzer based on cavity ring-down spectroscopy, an optical technology in which direct measurement of infrared absorption loss in a sample cell is used to quantify the mole fraction of the gas. This instrument ( $S / N$ DFADS2006, Picarro, Inc., Santa Clara, CA) is a custom analyzer based upon a standard $\mathrm{C}_{2} \mathrm{H}_{2} / \mathrm{CH}_{4} / \mathrm{H}_{2} \mathrm{O}$ model (G2203, Picarro, Inc., Santa Clara, $\mathrm{CA})$ to which a high precision $\mathrm{CO}_{2}$ measurement was added (Crosson, 2008). The inherent stability of the CRDS instrument allows it, when properly calibrated to traceable reference standards, to deliver accurate measurements that need very infrequent calibration relative to other $\mathrm{CO}_{2}$ and $\mathrm{CH}_{4}$ instrumentation. The overall measurement interval is just below $1 \mathrm{~s}$ (i.e., one to two measurements registered during $1 \mathrm{~s})$. There are two modes of operation for this analyzer: a $\mathrm{C}_{2} \mathrm{H}_{2} / \mathrm{CH}_{4} / \mathrm{H}_{2} \mathrm{O}$ mode and a $\mathrm{CO}_{2} / \mathrm{CH}_{4} / \mathrm{H}_{2} \mathrm{O}$ mode. The spectroscopy of $\mathrm{CO}_{2}, \mathrm{CH}_{4}$ and $\mathrm{H}_{2} \mathrm{O}$ is identical to the algorithms that are used in several standard models from the same manufacturer (e.g., models G1301, G2301, G2401); the performance of these instruments for atmospheric measurements of $\mathrm{CO}_{2}, \mathrm{CH}_{4}$ and $\mathrm{H}_{2} \mathrm{O}$ has been described in detail elsewhere (Crosson, 2008; Chen et al., 2010; Winderlich et al., 2010; Rella et al., 2013; Fang et al., 2013). The basic performance reported in these papers should be highly representative of the performance of this analyzer. For the $\mathrm{C}_{2} \mathrm{H}_{2} / \mathrm{CH}_{4}$ mode, the performances are described in details in Mønster et al. (2014b). A series of laboratory tests was performed in order to establish the basic performance of the analyzer, consisting of continuous measurements on prepared gas mixtures. The uncertainty calculated from these tests is summarized in Table 1. The $\mathrm{CH}_{4}$ measurements were calibrated in the field using the same calibration gases as the LSCE FTIR. The $\mathrm{C}_{2} \mathrm{H}_{2}$ measurement was not calibrated directly with a standard gas but using another instrument. For our purpose, the instrument was installed in the back of a car and was powered by the car battery. It was connected to a GPS mounted on the car roof and to internet via a $3 \mathrm{G}$ router. This allowed us to visualize in real time the location and intensity of the concentrations we were measuring and to ensure we are totally crossing the emission plumes. The air inlet is fixed on the GPS and its length is about $1 \mathrm{~m}$ long.

The scope of this campaign was to test the tracer release method to estimate the whole site emissions using mobile measurements. Three releases were performed in that manner. However, when the wind conditions were favorable, one stationary experiment, focusing on a single element of the site, was also performed. The typical transects for the mobile measurements as well as the location of the stationary experiment are indicated on Fig. 1. Mobile measurements occurred on 17 and 18 September while fixed measurements with the inlet next to the LSCE FTIR inlet were performed during the night of 19-20 September. During the first three releases, a $0.05 \mathrm{~m}^{3}$ cylinder of $\mathrm{C}_{2} \mathrm{H}_{2}$ was situated next to the degassing basin. The flow is controlled with a glass tube flowmeter (Sho-Rate from Brooks) with a precision better than $5 \%$ and a reproducibility of $0.5 \%$. During the first release episode, the wind was coming from the south. Using the nearby bridge above the Rhône (about $500 \mathrm{~m}$ away), we transected the plumes about 10 times. The plumes were located on the bridge and we drove before and after for at least the same distance as the length of the bridge to ensure that we were back on background levels. The flow on the flowmeter was fixed at $40 \mathrm{~mm}$ which translates to $10.3 \mathrm{~kg} \mathrm{day}^{-1}$. Later that day, a stationary experiment was performed to measure the emissions from the degassing basin with the car parked about $65 \mathrm{~m}$ away from it and the flowmeter was adjusted to a flow of $10.6 \mathrm{~kg} \mathrm{day}^{-1}$. The $\mathrm{C}_{2} \mathrm{H}_{2}$ gas cylinder was situated on the eastern edge of the degassing basin, about $7 \mathrm{~m}$ east of the center of the $5 \mathrm{~m}$ radius basin. On 19 September, the wind was stronger and coming from the north. The instruments were driven along the roads south of the station about $400 \mathrm{~m}$ away to cross the plumes. As for the previous day, we ensured that the plumes were fully crossed. The flow on the flowmeter was adjusted to $105 \mathrm{~mm}$ to compensate for the stronger dispersion which translates to $27.8 \mathrm{~kg} \mathrm{day}^{-1}$. Finally, a last experiment with the $\mathrm{C}_{2} \mathrm{H}_{2}$ cylinder close to the clarification basin to the station was conducted.

\subsection{Weather station}

A weather station (WXT520, Vaisala) was installed next to the FTIR and radon analyzer inlets. Wind speed, wind direction, temperature, relative humidity and atmospheric pressure were measured every second and averaged every minute.

\section{Results}

In this section, we present first the weather conditions and the concentration measurements that allowed us to get a general picture of the site and to estimate our instruments comparability. Then, we show the results from the two methods to estimate $\mathrm{CH}_{4}$ emissions.

\subsection{Continuous ambient air measurements}

The $\mathrm{CH}_{4}$ concentrations from the LSCE FTIR analyzer, the wind speed, the wind direction and the temperature measured during the whole campaign (except the sampling above the basins) are shown in Fig. 4. Using the wind direction, we plotted the wind rose for the whole campaign. It can be seen from the wind rose and the time series that the wind varied between two major directions during the campaign: south-southwest (SSW) and northeast. During the first day, the wind was variable but came mainly from the SSW direction. On 17 September, the wind direction was the same and steadier. On 19 and 20 September, the wind direction was again more variable with northeast being the main direction. 
Temperatures followed a typical daily pattern and varied between 10 and $24^{\circ} \mathrm{C}$.

$\mathrm{CH}_{4}$ concentrations varied between 1900 and $3000 \mathrm{ppb}$. The gaps in the data correspond to calibration periods and sampling above the basins. The highest concentrations were observed on the first and last days matching stable air mass (almost no wind speed and quick changes in wind directions). We compared these data to a suburban site, Gif-sur-Yvette (about $50 \mathrm{~km}$ southwest of Paris), plotted in grey in the upper panel. We see that the concentrations measured there did not present peaks like measured at the WWTP. This supports the hypothesis of very local emissions from the plant elevating the measured concentrations up to $1000 \mathrm{ppb}$ above what is observed in suburban area sites that are not located on a local source spot. On the concentration wind rose, we observed no preferential direction of higher concentrations. Note that for the direction with few data and low wind speed, we observed high concentrations that can be expected from a slower dispersion.

\subsection{Instrument comparison}

During the last night (20 to 21 September), the CRDS and the FTIR analyzers inlet lines were placed next to each other to sample the same air. The comparison of the two is shown in Fig. 5. Contrary to the FTIR analyzer, which was calibrated regularly during the entire campaign, the CRDS analyzer was calibrated only once before the in situ measurements. However, a good agreement was observed between the two instruments with a mean difference of $2.4 \pm 3.9 \mathrm{ppb}(\mathrm{SD})$. The WMO recommendation for laboratory intercomparison is $<2 \mathrm{ppb}$ in background air (WMO, 2011). We can then reasonably expect that if we had calibrated the CRDS instrument more often, we would have reached the recommended goal even for polluted air masses. Indeed, more frequent calibrations would have helped to compensate the temperature and atmospheric pressure influences on the measurements. However, the best solution would be to have the instruments in insulated shelters. Moreover, in the case of the tracer release, no calibration is needed as the instrument is linear in the range of measured concentrations and we use differences to the background to infer the fluxes.

\subsection{Process-scale measurements and fluxes}

\section{Clarification basin}

During the floating chamber deployment (accumulation mode), the $\mathrm{CH}_{4}$ concentration increased in the chamber over time. A total of eight chamber runs were made on the clarification basin. Where possible (see discussion below), the increase was approximated by linear least-square fitting and the fluxes were calculated. Only four out of eight floating chamber measurements on the clarification basin exhibited an approximately linear increase (chamber runs 2 (from minute
Table 2. Fluxes measured during chamber measurements on the clarification basin.

\begin{tabular}{cccc}
\hline & $\begin{array}{c}\text { Chamber } \\
\text { run no. }\end{array}$ & Mixer & $\mathrm{CH}_{4}$ flux $\left(\mathrm{mg} \mathrm{min}^{-1}\right)$ \\
\hline Diffusive $_{\text {emissions }^{\mathrm{a}}}$ & 2 & Off & $2.2 \pm 0.1$ \\
& 3 & Off & $2.2 \pm 0.1$ \\
& 4 & Off & $3.1 \pm 0.2$ \\
\hline Erratic $_{\text {emissions }} \mathrm{b}$ & 1 & On & $7.6 \pm 0.4$ \\
& 5 & Off & $108.5 \pm 6.4$ \\
& 8 & On & $168.8 \pm 9.9$ \\
& 9 & On & $72.9 \pm 4.3$ \\
& & & $18.5 \pm 1.1$ \\
\hline
\end{tabular}

a The fluxes were calculated by a linear fit because diffusive flux could be assumed.

$\mathrm{b}$ The observed concentration increase was not linear. The numbers are based on a linear fit of the steepest increase over a $10 \mathrm{~min}$ period. The fluxes calculated represent an upper limit.

7 on), 3, 4, 7; see Fig. 6b-d and f). The emissions calculated from these measurements averaged $3.8 \mathrm{mg} \mathrm{min}^{-1}$ (for the individual values see Table 2). The standard deviation, calculated to assess the spread of the individual measurements, was $2.6 \mathrm{mg} \mathrm{min}^{-1}$. It is reasonable that upscaling to the whole basin introduced uncertainty when not all locations on the basin were covered by our measurements. The uncertainty in volume and area contributed to the squared total error by 52 and $48 \%$, respectively, for all four diffusive flux measurements. The uncertainties associated with $\mathrm{CV}$, pressure and temperature were negligible. Based on our four measurements, we consider the obtained average of $3.8 \mathrm{mg} \mathrm{min}^{-1}$ or $5.4 \mathrm{~g} \mathrm{day}^{-1}$ to give the order of magnitude of the diffusive exchange flux, which represents the lower limit of the total emissions from the clarification basin. For the other four measurements (see Fig. 6a, e, g and h), the increase cannot be linearly approximated. Due to the very sudden increase of the methane concentration in the chamber, we think that erratic methane emissions caused this nonlinearity, i.e., ebullition. Since such events might occur more frequently close to the rotating arm and the number of measurements is too small for estimating the frequency of such events, it is difficult to estimate the basin methane flux generated by erratic events. However, we can state that the highest average flux for these measurements over a $10 \mathrm{~min}$ period was $169 \mathrm{mg} \mathrm{min}^{-1}$ (chamber run 5, Fig. 6e).

Overall it can be stated that the fluxes of methane were higher when the mixer was on and the arm rotated. The rotating arm extended down through the water column and caused increased turbulence at the water-air interface, throughout the water column and within the methane-rich sediments. The increased turbulence combined with resultant release of methane from the sediments could very likely explain the elevated flux and the high variability of the fluxes whilst the mixer was on. Runs 1 and 5 both show a high $\mathrm{CH}_{4}$ flux that differs remarkably from the other chamber runs. These runs 

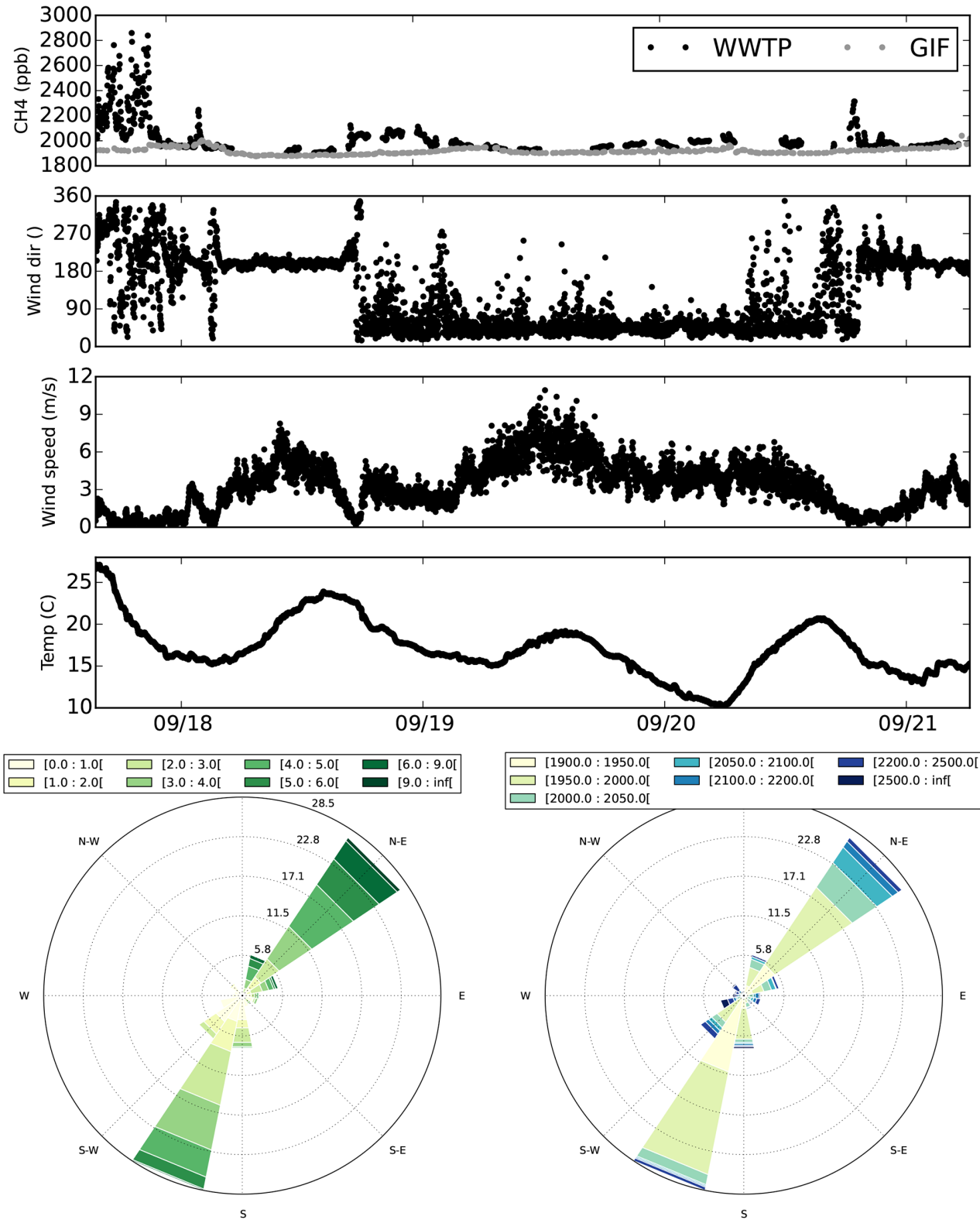

Figure 4. Upper panel: $\mathrm{CH}_{4}$ concentrations from the LSCE FTIR analyzer at Valence and from the suburban station of Gif-sur-Yvette, wind speed, wind direction and temperature during the campaign. Lower panel: wind roses of the wind speed $\left(\mathrm{m} \mathrm{s}^{-1}\right)$ and $^{-\mathrm{CH}_{4}}$ concentration (ppb) during the campaign.

were the first measurements conducted after the mixer was turned off (run 1) and on (run 5). The switching of the mixer on and off may have momentarily increased ebullition, resulting in the nonlinear and rapid increase of the concentration in the chamber (see Fig. 6a and e). Repeated measurements at different locations in the basin and under different conditions (mixer on/off) could further reveal the actual pattern of the fluxes from the clarification basin.

Considering the lower limit (diffusive flux) of the observed fluxes, we can state that the emissions from the clarification basin due to diffusive emissions are about $5.4 \pm 3.0 \mathrm{~g} \mathrm{day}^{-1}$.
In addition to the diffusive emissions, we observed erratic methane emissions, most likely due to bubbles, which would explain the very sudden increase to very high methane concentrations. Within the short time of measurements on the basin (1 day), it was not possible to do a systematic study of the methane emissions due to these erratic events. Therefore, here we can only provide an approximate estimate for erratic fluxes from the basin. We choose this approximate estimate in a way that it expresses the maximum erratic flux that we can consider possible according to our measurements. For this, we took the highest of the four erratic fluxes we mea- 


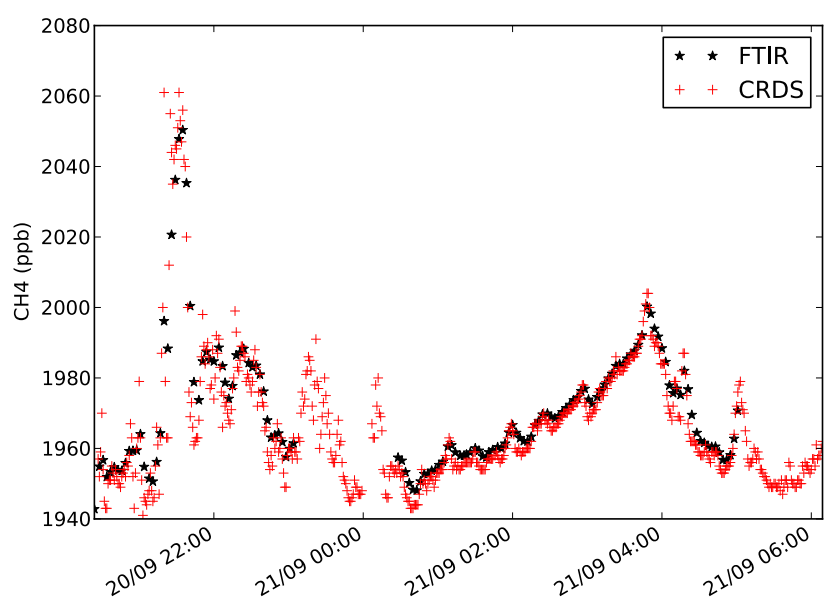

Figure 5. Comparison of $\mathrm{CH}_{4}$ concentrations from the LSCE FTIR and CRDS analyzers during the night of 20 September.
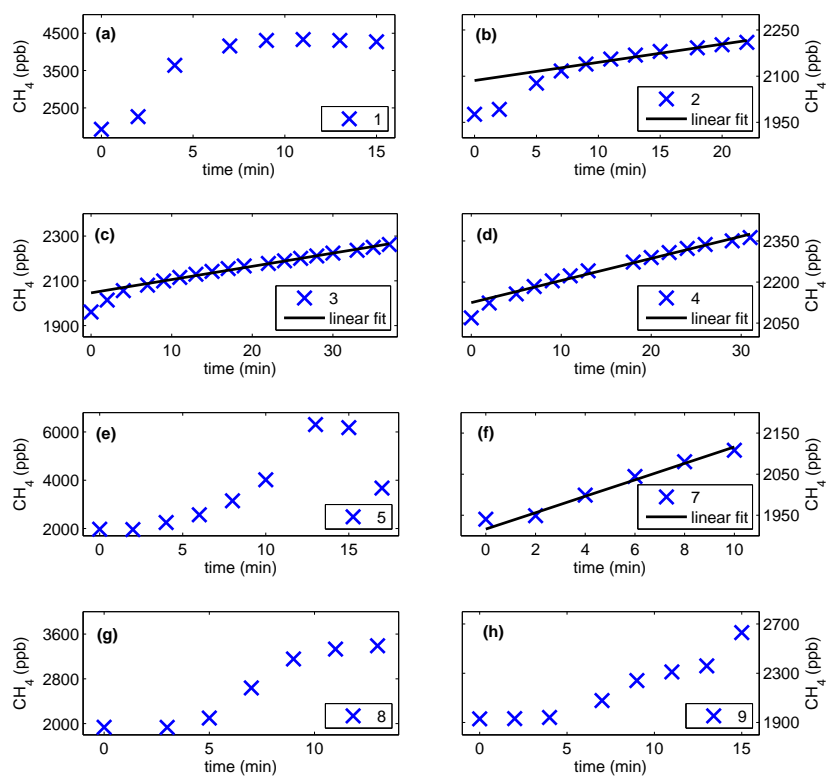

Figure 6. Floating chamber experiments conducted on the clarification basin when the mixer was off $(\mathbf{a}-\mathbf{d})$ and on $(\mathbf{e}-\mathbf{h})$, respectively.

sured and assumed that this flux, measured over $10 \mathrm{~min}$, occurred for $24 \mathrm{~h}$ over the entire area of the basin. In that case, the emissions would sum up to $243 \mathrm{~g}$ day $^{-1}$.

\section{Aeration basin}

The fluxes from outside of the aeration area and their uncertainties were derived in the same way as for the diffusive emissions from the clarification basin. We calculated a mean flux of $36 \pm 2 \mathrm{gday}^{-1}\left(38 \pm 2\right.$ and $34 \pm 2 \mathrm{gday}^{-1}$ ). This is more than 6 times higher than the diffusive flux measured on the clarification basin. We have no measurement for nonlinear fluxes on the aeration basin, therefore, the value given here $\left(36 \mathrm{~g} \mathrm{day}^{-1}\right)$ is a conservative estimate including the dif-
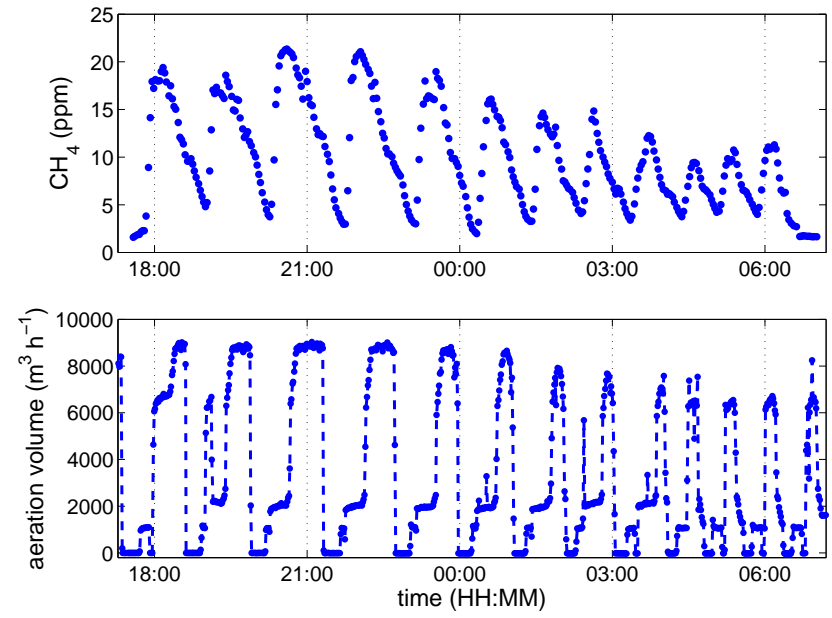

Figure 7. Measurements in the aeration area of the basin. Upper panel: methane concentration vs. time. Lower panel: respective volume of injected air during the same time period.

fusive flux only and would represent the lower limit of the total flux (diffusive + erratic) from this area. The fluxes are very different where the aeration takes place. There, the floating chamber was operated in flow-through mode over night. Figure 7 shows the $\mathrm{CH}_{4}$ mixing ratios in the chamber (upper panel) and the amount of injected air (lower panel). It can be seen that when the aeration starts, the methane concentration rises up to a maximum and already decreases before the aeration stops. We think that during the phases when no air and thus no oxygen is injected, there is a buildup of methane in the basin. Once the aeration starts, the methane is emitted from the basin with the aeration air.

The night measurements cover approximately $13 \mathrm{~h}$ and are therefore believed to offer a reasonably good temporal coverage for upscaling. We calculated the $\mathrm{CH}_{4}$ emissions with Eq. (2), with a background concentration of $1973 \mathrm{ppb}$, which is the average ambient $\mathrm{CH}_{4}$ measured with the LSCE FTIR during the night from 19 to 20 September. Accordingly, $553 \pm 17 \mathrm{~g} \mathrm{day}^{-1}$ was emitted from the aeration basin (with the uncertainty of the background $\mathrm{CH}_{4}$ concentration, taken as the largest deviation from the mean, equal to $2.5 \%$ ).

It can further be seen from Fig. 7 that the methane concentration maxima are lower during the late night than in the evening. In fact, an overall decrease of the maxima can be observed, along with shorter periods of non-aeration. Figure 8 indicates a linear correlation between the length of the non-aeration period and the methane maximum that is observed during the subsequent chamber measurement (correlation coefficient $R=0.86$ ). This supports our hypothesis that methane production occurs during non-aeration times, which is, in turn, responsible for the high methane emitted in the subsequent aeration phase. 


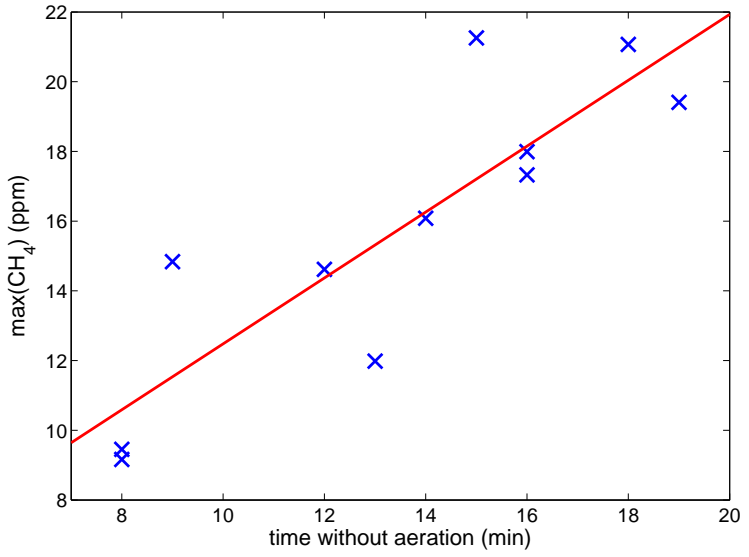

Figure 8. Methane maxima reached during the night chamber measurement vs. time without aeration. Blue are measurements; red is the linear fit.

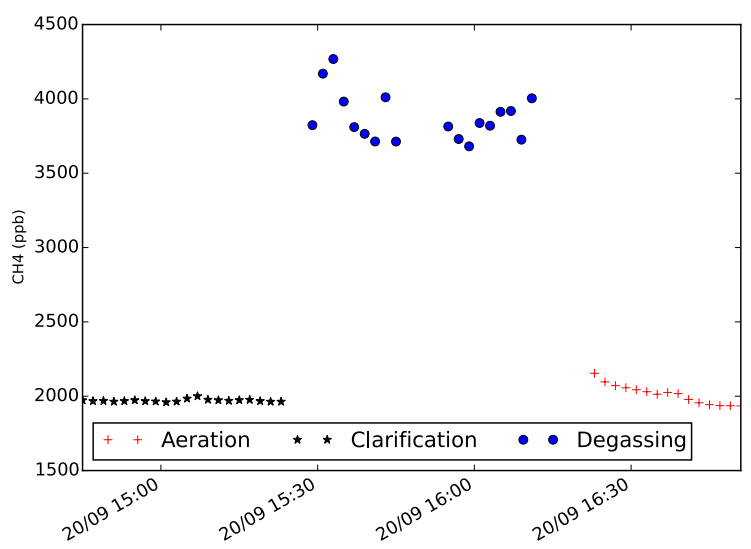

Figure 9. $\mathrm{CH}_{4}$ concentrations measured by the LSCE FTIR analyzer over the different basins.

\section{Degassing basin}

It was not possible to measure the small degassing basin that feeds the clarification basins using the floating chamber method due to the obstructed access to this basin. However, measurements above the clarification, aeration and degassing basins were performed with the LSCE FTIR analyzer sampling inlet $50 \mathrm{~cm}$ above the basins (see Fig. 9). For the aeration and the clarification basins, the concentrations at the time of measurement were close to the concentrations measured for the whole station. For the degassing basin, elevated concentrations of $\mathrm{CH}_{4}$ are measured up to $4300 \mathrm{ppb}$. The mobile CRDS $\mathrm{CH}_{4} / \mathrm{C}_{2} \mathrm{H}_{2}$ instrument was also used to quantify the emissions from this source. On 18 September, with winds originating from the SSW, driving both immediately upwind and downwind of this basin (within $10 \mathrm{~m}$ ) and the nearby clarification basin, a clear and distinct plume from this basin was identified. No significant emissions were observed from any of the clarification basins consistent with the floating chamber measurements. The measurement vehicle was parked at a distance about 9 times greater than the separation of the $\mathrm{C}_{2} \mathrm{H}_{2}$ and $\mathrm{CH}_{4}$ sources. We expect the plumes should be reasonably mixed at this distance, especially given the strong afternoon turbulent mixing of the atmosphere when these measurements were made (see Fig. 4). Under these well-mixed conditions, the static plume correlation method can be employed to estimate the emissions of $\mathrm{CH}_{4}$. About half an hour of $\mathrm{CH}_{4}$ and $\mathrm{C}_{2} \mathrm{H}_{2}$ measurements were made at this location, with the wind wafting the plumes back and forth across the measurement location. The winds came reliably from the SSW during this time, meaning that the measurements were not polluted by methane from the aeration basins or incineration building. The time series of $\mathrm{C}_{2} \mathrm{H}_{2}$ and $\mathrm{CH}_{4}$ are shown in Fig. 10b. The signals are clearly correlated. We plotted methane as function of $\mathrm{C}_{2} \mathrm{H}_{2}$ and fitted the resulting distribution with a linear function. The fit has a slope of $0.244 \mathrm{ppb}_{\mathrm{CH}_{4}} \mathrm{ppb}^{-1} \mathrm{C}_{2} \mathrm{H}_{2}$, with an $R^{2}$ of 0.62 . Given the release rate of $10.6 \mathrm{~kg} \mathrm{day}^{-1}$ for $\mathrm{C}_{2} \mathrm{H}_{2}$, we found that the methane emissions from the degassing basin were $1.13 \pm 0.5 \mathrm{~kg} \mathrm{day}^{-1}$. Given the wind direction, this emission number could include emissions from one or more of the clarification basins. However, whilst the floating chamber measurements showed that maximum emissions from the clarification basins were comparable $\left(0.8 \mathrm{~kg} \mathrm{day}^{-1}\right)$, on average they were about one-quarter of this amount. As this figure includes erratic fluxes, for which a conservative upper limit was given, the true fluxes are likely to be much lower. For example, if only diffusive emissions were included, then the flux would be smaller than $0.025 \mathrm{~kg} \mathrm{~d}^{-1}$ per basin. This compares to $1.135 \mathrm{~kg} \mathrm{~d}^{-1}$ from the degassing basin. Conclusively, the emissions from the clarification basin contribute only very little to the emissions from aquatic surfaces in the WWTP.

\subsection{Plant scale}

Figure 10a and c present measurements from $\mathrm{CH}_{4}$ and $\mathrm{C}_{2} \mathrm{H}_{2}$ during the two successful tracer release episodes using dynamic measurements. We see that the acetylene baseline is very close to 0 and stable, while the $\mathrm{CH}_{4}$ baseline varies between the releases and during them. The elevation of the signal above the background is on average $15-20 \mathrm{ppb}$ for $\mathrm{CH}_{4}$ and between 2 and $16 \mathrm{ppb}$ for $\mathrm{C}_{2} \mathrm{H}_{2}$ which is 5 to 20 times lower than for the static measurements reflecting the distance to the sources compared to the static measurements. The ratio for each numbered peak was calculated and the results and their uncertainties are summed up in Table 3. We observe a large variability (approximately $35 \%$ ) between the plumes but with a consistent average between the two mobile release episodes. The average value over the 2 days is $34.2 \pm 11.6 \mathrm{~kg} \mathrm{day}^{-1}$ or $83 \pm 28 \mathrm{~g} \mathrm{yr}^{-1}$ per inhabitant. The errors here represent the SD of the measurements and therefore also include the emission variability. 
Table 3. $\mathrm{CH}_{4}$ emissions $\left(\mathrm{kg} \mathrm{day}^{-1}\right)$ for the whole station using the tracer release method.

\begin{tabular}{ccccc}
\hline & North wind & & \multicolumn{2}{c}{ South wind } \\
\cline { 1 - 2 } \cline { 5 - 5 } Transect & $\mathrm{CH}_{4}$ emissions $\left(\mathrm{kg} \mathrm{day}^{-1}\right)$ & & Transect & $\mathrm{CH}_{4}$ emissions \\
\hline 1 & $19.1 \pm 0.5$ & & 1 & $28.7 \pm 0.5$ \\
2 & $21.0 \pm 0.5$ & & 2 & $49.6 \pm 0.5$ \\
3 & $48.1 \pm 0.5$ & & 3 & $30.0 \pm 0.5$ \\
4 & $42.1 \pm 0.5$ & & 4 & $25.0 \pm 0.5$ \\
5 & $47.3 \pm 0.5$ & & 6 & $18.6 \pm 0.5$ \\
6 & $35.9 \pm 0.5$ & & 7 & $31.0 \pm 0.5$ \\
7 & $46.3 \pm 0.5$ & & 8 & \\
8 & $22.9 \pm 0.5$ & & Average & $32.9 \pm 11.35$ \\
\hline Average & $35.3 \pm 12.5$ & \multicolumn{3}{c}{}
\end{tabular}

\section{Discussion}

\subsection{Uncertainties}

In this paper, we used two methods to estimate emissions with associated uncertainties. These uncertainties and the parameters they arise from are summarized in Table 4. Depending on the methods, the uncertainties range from 5 to $60 \%$. However, in most cases there are several parameters that can be determined more accurately to reduce these uncertainties. In Table 4 the parameters in bold are the parameters with the higher uncertainty.

In the case of the closed chamber, the water area enclosed by the chamber and the air volume in the chamber are the parameters associated with the strongest uncertainties. They eventually depend on the uncertainty of the water level. Consequently, a more accurate measurement of the water level in the chamber and a minimization of its variation should be aimed at if lowering of the total uncertainty is desired. The error associated with the water surface area can be fully eliminated by choosing a box over a conic chamber. With a box, the variation of the water level would not affect the surface area across which the exchange takes place.

For the open-chamber measurements, the uncertainty comes mostly from the injected air flow measurement and is related to the WWTP equipment (in this case the measurement uncertainty is $2 \%$ ).

For the tracer release method, the largest uncertainties come from the collocation assumption of the signals and the baseline estimates. These uncertainties can be reduced by lengthening the period of "clean" air measurement between each plume crossing and by ensuring that the signals are correlated. Moreover, controlled release exercises as done by Mønster et al. (2014b) can help quantify the non-collocation error. In our study, when the acetylene cylinder was located near the degassing basin, the two signals were slightly shifted in time (not shown) depending on the direction we were driving. This shows that this location was not optimal for sampling the methane emissions from the station when still close to it (about $500 \mathrm{~m}$ ). Judging by the horizontal displacement
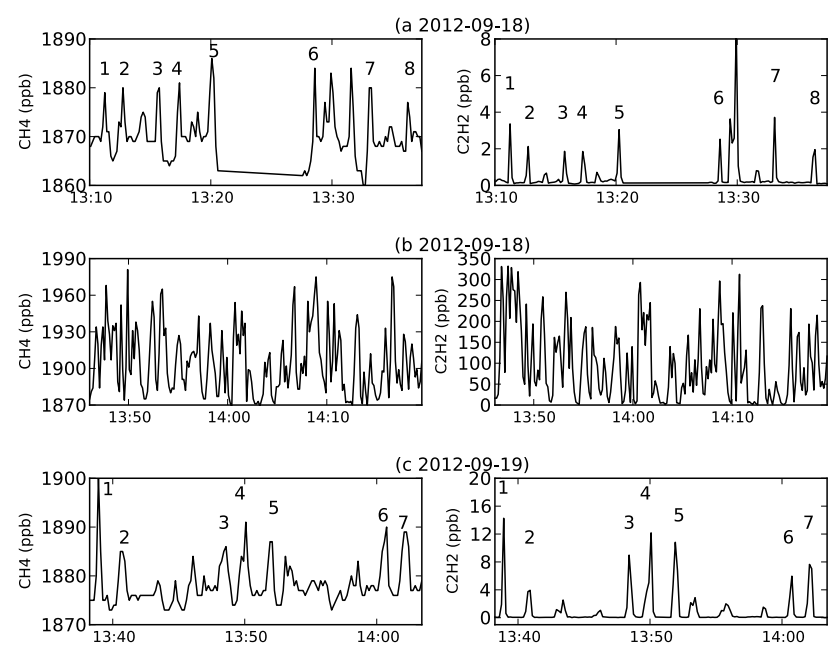

Figure 10. Concentrations of $\mathrm{CH}_{4}$ and $\mathrm{C}_{2} \mathrm{H}_{2}$ during the three tracer release episodes. Episode (a): estimation of the whole plant emission on 18 September with a south wind; the $\mathrm{C}_{2} \mathrm{H}_{2}$ cylinder is located in A (see Fig. 1). Episode (b): estimation of the degassing basin emissions on 18 September with a south wind; the $\mathrm{C}_{2} \mathrm{H}_{2}$ cylinder is located in A. Episode (c): estimation of the whole plant emissions on 19 September with a north wind; the $\mathrm{C}_{2} \mathrm{H}_{2}$ cylinder is located in A. The numbers indicate the signals (peaks) that are used to calculate the $\mathrm{CH}_{4}$ emissions.

of the plumes with respect to each other, and the direction of the wind, there was another methane source west of the degassing basin. When the cylinder was moved to the clarification basin, we observed an opposite horizontal displacement, which indicates that the cylinder was now located west to the axis of the methane plume propagating in the direction of the wind. It seems then that the optimal location would have been near the LSCE FTIR sampling lines. This means a displacement of about $50 \mathrm{~m}$, which translates into an underestimation of $10-15 \%$ on the flux (Mønster et al., 2014b). This would translate into an average flux of about $38.9 \mathrm{~kg} \mathrm{day}^{-1}$, which lies within our uncertainty estimate $\left(11.6 \mathrm{~kg} \mathrm{day}^{-1}\right)$.

In summary, there is potential to reduce the uncertainty of each method, which should be considered when aiming for more robust WWTP emission estimates. Moreover, longer measurement campaigns over different times of the year would also allow us to catch the variability of the emissions of the site. Finally, if aiming for a general estimates, several WWTPs have to be investigated.

\subsection{First insights into the Valence WWTP methane emissions}

The results from the chamber and the tracer release measurements are summarized in Table 5. If we add the maximum contribution from the different basins, the emissions are approximately $3.1 \mathrm{~kg} \mathrm{day}^{-1}$, i.e., $8 \%$ of the total emissions observed from the facility using the tracer dilution method. We confirm then that the main source of emissions from the 
Table 4. Summary of the uncertainties resulting from the different methods (in percent). The parameters with the higher uncertainty are in bold.

\begin{tabular}{llll}
\hline & Closed chamber & Open chamber & Tracer release \\
\hline $\begin{array}{l}\text { Uncertainties } \\
\text { Parameters }\end{array}$ & $\begin{array}{l}\text { 6-60 } \\
\text { mixing ratio, chamber sur- } \\
\text { face area and volume, } \\
\text { pressure, temperature, lin- } \\
\text { ear fit }\end{array}$ & $\begin{array}{l}15 \\
\text { mixing ratios, acetylene }\end{array}$ \\
& & $\begin{array}{l}\text { flux, correlation, baseline } \\
\text { estimates }\end{array}$ \\
\hline
\end{tabular}

Table 5. Summary of the results from the process to the site scale. The given uncertainties were determined in different ways. Refer to the main text for details.

\begin{tabular}{|c|c|c|c|c|c|}
\hline & $\begin{array}{l}\text { Clarification } \\
\text { basins ( } 3 \text { ) }\end{array}$ & $\begin{array}{l}\text { Aeration basins ( } 2) \\
\text { non-aeration area }\end{array}$ & $\begin{array}{l}\text { Aeration basins (2) } \\
\text { aeration area }\end{array}$ & Degassing basin (1) & WWTP \\
\hline \multirow{2}{*}{$\begin{array}{l}\mathrm{CH}_{4} \text { emissions } \\
\left(\mathrm{kg} \mathrm{day}^{-1}\right)\end{array}$} & $0.02 \pm 0.01$ & $0.07 \pm 0.01$ & $1.11 \pm 0.03$ & $1.13 \pm 0.24$ & $34.2 \pm 11.6$ \\
\hline & $\begin{array}{l}+ \text { emissions by } \\
\text { erratic events (at most } \\
0.77 \pm 0.05)\end{array}$ & $\begin{array}{l}\text { + emissions by } \\
\text { erratic events (not } \\
\text { determined) }\end{array}$ & & & \\
\hline
\end{tabular}

plant is not these basins but is located elsewhere, as shown in Fig. 1d.

In other studies presented in Daelman et al. (2012), the emissions from municipal waste water treatment plants using activated sludge treatment, such as the Valence plant, varied from 39 to $306 \mathrm{~g} \mathrm{yr}^{-1}$ per inhabitant. The higher limit was found for a plant using a sludge digester producing biogas. This unit was found to emit three-quarters of the total emissions of the plant, leaving approximately $77 \mathrm{~g} \mathrm{yr}^{-1}$ per inhabitant emitted by the other processes. The Valence plant estimate agrees with this last value ( $83 \mathrm{~g} \mathrm{yr}^{-1}$ per inhabitant).

We can also compare this estimate with inventories estimates. The European Database for Global Atmospheric Research (EDGAR, Olivier et al. (1996), which provides gridded maps, and the CITEPA, which is responsible for the French inventory, use the IPCC methodology to estimate $\mathrm{CH}_{4}$ emission factors from WWTPs (see Eq. 4).

$E F=\mathrm{BOD} \times 365 . B o \times \sum_{x}(W S x \cdot M C F x)$,

where $\mathrm{Bo}$ is the maximum $\mathrm{CH}_{4}$ production capacity, $W S_{x}$ is the percentage of a certain process used in the WWTP and $M C F_{x}$ is the conversion rate of this process. According to the hypothesis, the conversion rate for a WWTP like Valence (aerobic treatment) should be at the maximum 0.1 with a maximum of 0.4 if not well managed (IPCC chapter 6 table 6.3, http://www.ipcc-nggip.iges.or.jp/public/2006gl/ pdf/5_Volume5/V5_6_Ch6_Wastewater.pdf). The Bo is usually estimated to be $0.6 \mathrm{~kg}_{\mathrm{CH} 4} \mathrm{~kg}^{-1}$ BOD. CITEPA estimates for France an average emission factor of $74 \mathrm{~g} \mathrm{yr}^{-1}$ per inhabitant, which is very close to the Valence estimate. Using the data from the WWTP, we can calculate the conversion rate and compare it to the awaited value. Here, we find a conver- sion rate of 0.07 , which is in the expected range. From these first measurements, it seems then that the Valence WWTP is an average French WWTP in terms of $\mathrm{CH}_{4}$ emissions.

\section{Conclusions}

We measured $\mathrm{CH}_{4}$ at one of the waste water treatment plants in the city of Valence, France. Two instruments - FTIR and CRDS - combined with different methods - floating chamber and tracer release - were used. They allowed us to span several scales from the individual process to the site.

The duration of the campaign, 4 days only, was too short to accurately quantify the emissions and sample the site variability. However, we have shown that these methods are suitable to evaluate emissions at these different scales and that they complement each other. The estimated uncertainty for any of the methods is under $60 \%$ and could in most cases be reduced by more experiments (e.g., controlled release for the tracer release method) or by a more precise measurement of the experiment apparatus (e.g., the area of the chamber in contact with the water). From a qualitative point of view, the emissions from the waste water plant are representative of an average French WWTP. The estimates on three structures from the plant, the aeration, clarification and degassing basins, show that even though these are the largest open structures on site, they are not the main emitters of methane on the plant. Concentration measurements seem to indicate that the incinerator building and the pretreatment could be the main sources. Finally, these estimates are in the same range of values as found in the literature.

This study demonstrates the use of new techniques, FTIR and CRDS analyzers, to estimate small-scale emissions and 
help improve emission factors for bottom-up inventories. Longer periods of measurements are, however, necessary to be able to sample statistically significant numbers of events and get more accurate emission estimates.

Acknowledgements. We thank Veolia Eau and especially Julien Malandain, head of the waste water treatment network from Drôme-Ardèche, and all the staff including Sandy Chabanel, Cédric Comte, Yvan Blache and Nicolas Drut in the stations of Valence and Romans-sur-Isere for their technical help, great involvement and interest in the measurement campaign. We also thank the city of Valence for supporting this project. Thank you to Benoit Wastine and Cyrille Vuillemin from LSCE for their help in organizing the campaign. This campaign was funded through the BridGES project (supported by the Versailles Saint-Quentin-enYvelines University, the French Alternative Energies and Atomic Energy Commission (CEA), the French National Center for Scientific Research (CNRS) and Thales Alenia Space and Veolia Water).

Edited by: D. Feist

\section{References}

Bevington, P. R. and Robinson, D. K.: Data reduction and error analysis, McGraw-Hill, New York, USA, 2003.

Cakir, F. and Stenstrom, M.: Greenhouse gas production: a comparison between aerobic and anaerobic wastewater treatment technology, Water Res., 39, 4197-4203, doi:10.1016/j.watres.2005.07.042, 2005.

Chen, H., Winderlich, J., Gerbig, C., Hoefer, A., Rella, C. W., Crosson, E. R., Van Pelt, A. D., Steinbach, J., Kolle, O., Beck, V., Daube, B. C., Gottlieb, E. W., Chow, V. Y., Santoni, G. W., and Wofsy, S. C.: High-accuracy continuous airborne measurements of greenhouse gases $\left(\mathrm{CO}_{2}\right.$ and $\left.\mathrm{CH}_{4}\right)$ using the cavity ring-down spectroscopy (CRDS) technique, Atmos. Meas. Tech., 3, 375386, doi:10.5194/amt-3-375-2010, 2010.

CITEPA: Rapport national pour la France au titre de la convention cadre des Nations Unis sur le changement climatique et du protocole de Kyoto, Source CITEPA/ rapport CCNUCC édition de mars 2013, 66191 pp., available at: http://www. citepa.org/fr/activites/inventaires-des-emissions/ccnucc (last access: 14 March 2015), 2013.

Crosson, E. R.: A cavity ring-down analyzer for measuring atmospheric levels of methane, carbon dioxide, and water vapor, Appl. Phys. B, 92, 403-408, doi:10.1007/s00340-008-3135-y, 2008.

Czepiel, P. M., Crill, P. M., and Harriss, R. C.: Methane emissions from municipal wastewater treatment processes, Environ. Sci. Technol., 27, 2472-2477, doi:10.1021/es00048a025, 1993.

Czepiel, P. M., Mosher, B., Harriss, R. C., Shorter, J. H., McManus, J. B., Kolb, C. E., Allwine, E., and Lamb, B. K.: Landfill methane emissions measured by enclosure and atmospheric tracer methods, J. Geophys. Res.-Atmos., 101, 16711-16719, doi:10.1029/96JD00864, 1996.

Daelman, M. R. J., van Voorthuizen, E. M., van Dongen, U. G. J. M., Volcke, E. I. P., and van Loosdrecht, M. C. M.: Methane emission during municipal wastewater treatment, Water Res., 46, 36573670, doi:10.1016/j.watres.2012.04.024, 2012.

El-Fadel, M. and Massoud, M.: Methane emissions from wastewater management, Environ. Pollut., 114, 177-185, doi:10.1016/S0269-7491(00)00222-0, 2001.

Fang, S.-X., Zhou, L.-X., Masarie, K. A., Xu, L., and Rella, C. W.: Study of atmospheric $\mathrm{CH}_{4}$ mole fractions at three WMO/GAW stations in China, J. Geophys. Res.-Atmos., 118, 4874-4886, doi:10.1002/jgrd.50284, 2013.

Frankignoulle, M.: Field measurements of air-sea $\mathrm{CO}_{2}$ exchange, Limnol. Oceanogr., 33, 313-322, 1988.

Fredenslund, A. M., Scheutz, C., and Kjeldsen, P.: Tracer method to measure landfill gas emissions from leachate collection systems, Waste Manage., 30, 2146-2152, doi:10.1016/j.wasman.2010.03.013, 2010.

Galle, B., Samuelsson, J., Svensson, B. H., and Börjesson, G.: Measurements of methane emissions from landfills using a time correlation tracer method based on FTIR absorption spectroscopy, Environ. Sci. Technol., 35, 21-25, doi:10.1021/es0011008, 2001.

Griffith, D. W. T., Deutscher, N. M., Caldow, C., Kettlewell, G., Riggenbach, M., and Hammer, S.: A Fourier transform infrared trace gas and isotope analyser for atmospheric applications, Atmos. Meas. Tech., 5, 2481-2498, doi:10.5194/amt-5-2481-2012, 2012.

Hammer, S., Griffith, D. W. T., Konrad, G., Vardag, S., Caldow, C., and Levin, I.: Assessment of a multi-species in situ FTIR for precise atmospheric greenhouse gas observations, Atmos. Meas. Tech., 6, 1153-1170, doi:10.5194/amt-6-1153-2013, 2013.

Mønster, J., Scheutz, C., and Kjeldsen, P.: Quantifying greenhouse gas emissions from waste treatment facilities, $\mathrm{PhD}$ thesis, DTU Environment, Kgs. Lyngby, 2014a.

Mønster, J. G., Samuelsson, J., Kjeldsen, P., Rella, C. W., and Scheutz, C.: Quantifying methane emission from fugitive sources by combining tracer release and downwind measurements - a sensitivity analysis based on multiple field surveys, Waste Manage., 34, 1416-1428, doi:10.1016/j.wasman.2014.03.025, 2014b.

Olivier, J. G. J., Bouwman, A. F., van der Maas, C. W. M., Berdowski, J. J. M., Veldt, C., Bloos, J. P. J., Visschedijk, A. J. H., Zandveld, P. Y. J., and Haverlag, J. L.: Description of EDGAR Version 2.0: A set of global emission inventories of greenhouse gases and ozone-depleting substances for all anthropogenic and most natural sources on a per country basis and on $1^{\circ} \times 1^{\circ}$ grid, Rijksinstituut voor Volksgezondheid en Milieu RIVM, 1996.

Rella, C. W., Chen, H., Andrews, A. E., Filges, A., Gerbig, C., Hatakka, J., Karion, A., Miles, N. L., Richardson, S. J., Steinbacher, M., Sweeney, C., Wastine, B., and Zellweger, C.: High accuracy measurements of dry mole fractions of carbon dioxide and methane in humid air, Atmos. Meas. Tech., 6, 837-860, doi:10.5194/amt-6-837-2013, 2013.

Spokas, K., Bogner, J., Chanton, J., Morcet, M., Aran, C., Graff, C., Golvan, Y. M.-L., and Hebe, I.: Methane mass balance at three landfill sites: what is the efficiency of capture by gas collection systems?, Waste Manage., 26, 516-525, doi:10.1016/j.wasman.2005.07.021, 2006.

Stocker, T. F., Qin, D., Plattner, G.-K., Tignor, M., Allen, S. K., Boschung, J., Nauels, A., Xia, Y., Bex, V., and Midgley, P. M.: Climate Change 2013: The Physical Science Basis, Tech. rep., 1535 pp., 2013. 
Wang, J., Zhang, J., Xie, H., Qi, P., Ren, Y., and Hu, Z.: Methane emissions from a full-scale A/A/O wastewater treatment plant, Bioresource Technol., 102, 5479-5485, doi:10.1016/j.biortech.2010.10.090, 2011.

Winderlich, J., Chen, H., Gerbig, C., Seifert, T., Kolle, O., Lavrič, J. V., Kaiser, C., Höfer, A., and Heimann, M.: Continuous low-maintenance $\mathrm{CO}_{2} / \mathrm{CH}_{4} / \mathrm{H}_{2} \mathrm{O}$ measurements at the Zotino Tall Tower Observatory (ZOTTO) in Central Siberia, Atmos. Meas. Tech., 3, 1113-1128, doi:10.5194/amt-3-1113-2010, 2010.
WMO: 16th WMO/IAEA Meeting on Carbon Dioxide, Other Greenhouse Gases, and Related Measurement Techniques (GGMT-2011), available at: http://www.wmo.int/pages/prog/ arep/gaw/documents/Final_GAW_206_web.pdf (last access: 1 March 2015), 2011.

Yoshida, H., Mønster, J., and Scheutz, C.: Plant-integrated measurement of greenhouse gas emissions from a municipal wastewater treatment plant, Water Res., 61, 108-118, doi:10.1016/j.watres.2014.05.014, 2014. 